\title{
PENDIDIKAN DI DAERAH KEPULAUAN TERPENCIL: POTRET SISWA, GURU, DAN SUMBER BELAJAR
}

\author{
Imam Fitri Rahmadi \\ Fakultas Keguruan dan Ilmu Pendidikan, Universitas Pamulang \\ email: imamrahmadi@unpam.ac.id
}

\begin{abstract}
Education in the foremost, remote, and rural (3T) regions in Indonesia is known for its various complex problems. This research aims to look at the condition of students, teachers, and learning resources in schools at the Pongok and Celagen islands. This research uses a qualitative approach by case studies. This research involved all schools in the two islands. Data collection techniques used in this researsh are documentation study techniques. The results of this research revealed that very few graduates of High School at Pongok and Celagen went to college, there were still quite a number of teachers with non-educational undergraduate degrees, and there were almost no collections of educator manuals in the school library. The problem must be a serious concern for stakeholders and the policy to be overcome gradually and continuously.
\end{abstract}

Keyword: Education in rural areas, Pongok and Celagen islands.

Abstrak: Pendidikan di daerah terdepan, terluar, dan tertinggal (3T) di Indonesia terkenal dengan berbagai permasalahan yang kompleks. Penelitian ini bertujuan untuk melihat kondisi siswa, guru, dan sumber belajar pada sekolah di daerah kepulauan Pongok dan Celagen. Penelitian ini menggunakan pendekatan kualitatif dengan studi kasus. Penelitian ini melibatkan semua sekolah yang ada di kedua pulau tersebut. Teknik pengumpulan data yang digunakan dalam penelitian ini adalah teknik studi dokumentasi. Hasil penelitian mengungkapkan bahwa sangat sedikit lulusan siswa Sekolah Menengah Atas (SMA) di Pongok dan Celagen yang melanjutkan ke perguruan tinggi, masih terdapat cukup banyak guru yang berlatar belakang pendidikan strata 1 non-kependidikan, dan hampir tidak ada koleksi buku panduan pendidik di perpustakaan sekolah. Masalah tersebut harus menjadi perhatian yang serius bagi para pemangku kepentingan dan kebijakan agar segera diatasi secara bertahap dan berkelanjutan.

Kata kunci: Pendidikan di daerah 3T, pulau Pongok dan Celagen.

\section{PENDAHULUAN}

Pendidikan di daerah terdepan, terluar, dan tertinggal (3T) Indonesia terkenal unik dengan berbagai permasalahan kompleks. Seperti yang terjadi di perbatasan Entikong Sanggau Kalimantan Barat, sebuah kecamatan yang berbatasan langsung dengan Tebedu Serawak Malaysia, yang mengalami kurangnya tenaga pendidik dan kependidikan, rendahnya kesejahteraan guru, minimnya sarana dan prasarana, kurangnya kesempatan pemerataan pendidikan, dan budaya pendidikan yang masih rendah (Yosada, 2017). Fakta ini sebatas yang terjadi dalam lingkup kecil pada suatu kecamatan.

Pada skala yang lebih luas, Provinsi Kepulauan Riau mengalami berbagai kendala dalam pembangunan dunia pendidikan dikarenakan; 1) sarana dan prasaranan pendidikan yang belum memadai; 2) kondisi geografis yang terdiri atas pulau-pulau dengan jarak yang jauh; 3 ) mahalnya biaya pendidikan; dan 4) jumlah guru yang sedikit dengan kualitas rendah (Ginting, 2016). Baik dalam lingkup kecil 
pada suatu kecamatan atau lingkup besar pada suatu provinsi, nampaknya terdapat kompleksitas masalah yang sama terkait pendidikan di daerah yang termasuk dalam wilayah $3 \mathrm{~T}$.

Khususnya terkait dengan guru, terjadi fenomena unik yang disebut sebagai metrocentricity, yang didefiniskan oleh Campbell dan Yates (2011) sebagai " $a$ personal trait inhibiting teachers from considering country positions." Berdasarkan temuan penelitian tersebut, didapati bahwa para guru cenderung suka memilih-milih tempat untuk mengajar, sedangkan mayoritas pilihannya adalah mengajar di daerah perkotaan. Sangat sedikit guru yang dengan sukarela mau mengajar di daerah pedesaan terpencil (rural/remote areas). Bahkan, terindikasi bahwa para guru memiliki persepsi yang negatif dan sedikit sekali memiliki persepsi yang positif terhadap daerah terpencil.

Motivasi siswa juga menjadi konsern tersendiri karena siswa di daerah terpencil memiliki motivasi yang rendah dalam belajar terutama pada mata pelajaran matematika dan secara gabungan pada semua mata pelajaran (Handre, Sullivan, \& Crowson, 2009). Para siswa tidak benarbenar mengatahui mengapa mereka harus pergi ke sekolah. Siswa memiliki motivasi yang bervariasi terhadap suatu mata pelajaran, namun kecenderungannya, motivasi mereka sangat rendah pada mata pelajaran matematika. Konteks penelitian ini adalah 2 daerah terpencil di Amerika yang notabene merupakan negara maju, hasil penelitian dengan variable yang sama akan sangat mungkin mendapatkan hasil berbeda jika dilakukan pada daerah terpencil di suatu negara berkembang.

Berbagai penelitian yang telah dilakukan di daerah perbatasan Kayan Hulu Malinau (A'ing, 2015) dan Bintan Pesisir Kepulauan Riau (Auldina, 2018), di daerah terpencil Loru Sigi Biromaru (Imran, 2014) dan Buntu Mondong Enrekang (Suardi, Sulfasyah, \& Nur, 2016), serta di daerah kepulauan Pulau Nasi Aceh Besar (Adlim, Gusti, \& Zulfadli, 2016) dan kepulauan Talaud Sulawesi Utara (Londa, 2016) mendapatkan temuan serupa yang mengungkapkan bahwa kondisi dan pengembangan pendidikan di daerah tersebut masih sangat terbatas, bahkan cenderung didiskriminasikan dan dimarjinalkan.

Kondisi pendidikan di Indonesia secara umum juga tidak luput dari catatan buruk. Tujuh tahun silam, tepatnya pada tahun 2012, berdasarakan pemetaan Kementerian Pendidikan dan Kebudayaan terhadap 40.000 sekolah di Indonesia, 75\% di antaranya tidak memenuhi standar layak minimal pendidikan. Selain itu, hasil kompetensi guru terhadap 460.000 guru mendapatkan nilai rata-rata 44,5 dengan standar minimal yang diharapkan adalah 70 (Baswedan, 2014). Kondisi tujuh tahun yang lalu ini perlu dikonfirmasi kembali untuk melihat progress pengembangan dan pembangunan dalam bidang pendidikan.

Penelitian ini bermaksud untuk mengkonfirmasi beberapa temuan penelitian sebelumnya dengan berfokus pada komponen pembelajaran. Penelitian ini merupakan penelitian pendahuluan yang akan ditindaklanjuti dengan beberapa penelitian lanjutan. Pembelajaran yang merupakan proses interaksi antara siswa dengan guru dan sumber belajar pada suatu lingkungan belajar, menunjukkan bahwa terdapat 3 komponen penting yang terlibat dalam pembelajaran, yaitu siswa, guru, dan sumber belajar. Sumber belajar memiliki arti yang luas dan jenis yang sangat banyak, namun pada penelitian ini sumber belajar yang dilihat spesifik pada koleksi buku perpustakaan.

Penelitian dilakukan di daerah kepuauan terpencil bernama pulau Pongok dan Celagen. Kedua pulau tersebut 
tergolong sebagai daerah 3T di bawah wilayah administrasi Kecamatan Kepulauan Pongok, Kabupaten Bangka Selatan, Provinsi Kepulauan Bangka Belitung. Pulau Pongok dan Celagen merupakan dua pulau yang berbeda namun lokasinya sangat berdekatan. Keduanya hanya dipisahkan dengan laut dangkal yang bisa diseberangi menggunakan perahu kecil dengan jarak tempuh kurang dari 5 menit. Apabila dilihat pada peta, pulau Pongok memiliki nama yang berbeda, yaitu Pulau Liat. Berikut ini gambaran lokasi kedua pulau tersebut.

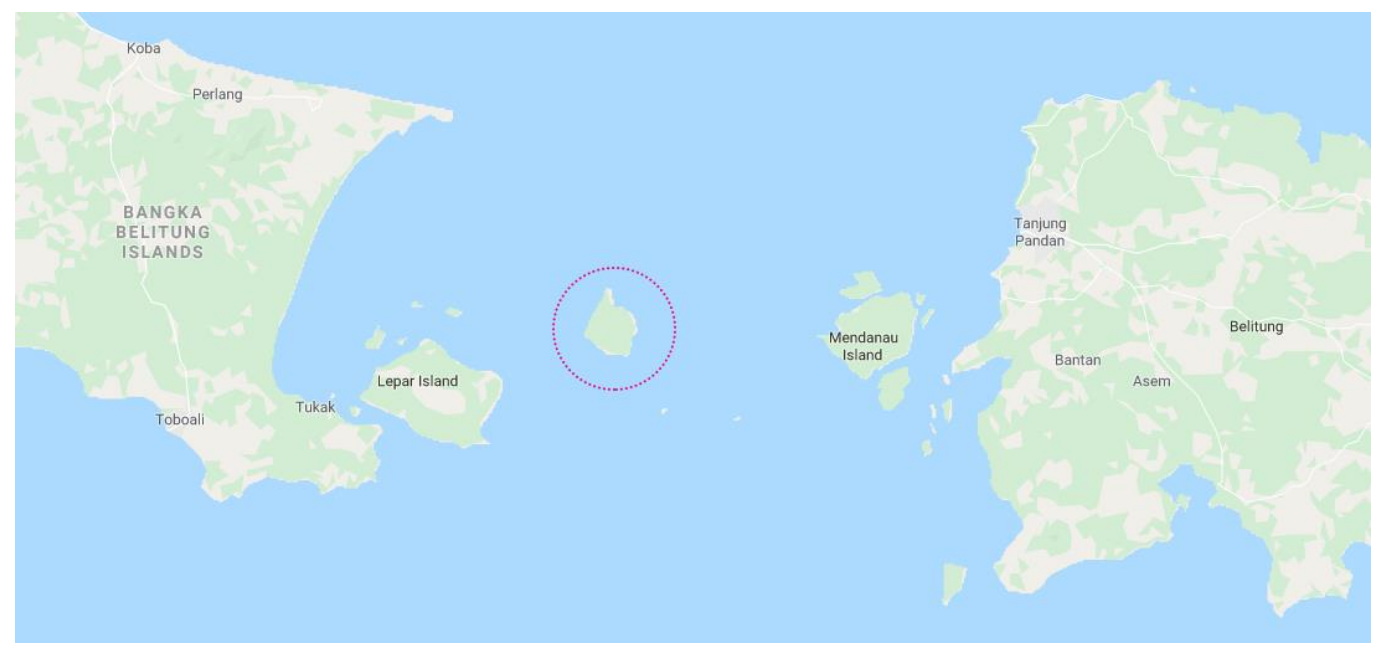

Gambar 1. Lokasi Pulau Pongok dan Celagen diambil dari Google Maps

Gambar 1. menunjukkan lokasi pulau Pongok dan Celagen. Lokasi kedua pulau tersebut dilingkari pada gambar. Pulau Pongok dan Celagen berada tepat di antara pula Bangka dan pulau Belitung. Lebih tepatnya, kedua pulau tersebut diapit oleh pulau Lepar dan pulau Mendanau. Pulau Celagen tidak terlihat karena sebetulnya pulau tersebut sangat kecil dengan luas hanya $3,54 \mathrm{~km}^{2}$, sedangkan pulau Pongok memiliki luas $48,35 \mathrm{~km}^{2}$ dengan penduduk berjumlah 5.377 jiwa (Badan Pusat Statistik Kabupaten Bangka Selatan, 2017). Perjalanan menuju pulau ini membutuhkan waktu sekitar 8 jam jika dimulai dari pusat kota Pangkalpinang dengan menempuh perjalanan darat selama 3-4 jam dan perjalanan laut menggunakan perahu motor kayu selama 3-4 jam.

Hasil penelitian diharapkan dapat memberikan gambaran nyata terhadap kondisi pendidikan di daerah kepulauan terpencil, khususnya yang berkaitan dengan kondisi siswa, guru, dan sumber belajar, bagi para pemangku kepentingan dan kebijakan dalam dunia pendidikan. Sehingga, diharapkan pengambilan kebutusan untuk pengembangan kebijakan pendidikan di daerah kepulauan terpencil bisa lebih tepat sasaran dan sesuai dengan kebutuhan nyata di lapangan. Selain itu, hasil penelitian ini semoga dapat menggugah kepedulian masyarakat luas terhadap kondisi pendidikan di daerah kepulauan terpencil yang masih perlu untuk terus dikembangkan.

\section{METODE PENELITIAN}

Penelitian merupakan suatu penelitian pendahuluan menggunakan pendekatan kualitatif dengan metode studi kasus. Penelitian pendahuluan ini dilakukan untuk mendapatkan gambaran kondisi nyata di lapangan yang mana setelah itu akan dilakukan beberapa penelitian lanjutan yang sesuai dengan masalah dan kebutuhan nyata 
objek penelitian. Penelitian dilakukan di pulau Pongok dan Celagen yang berada di bawah wilayah administrasi Kecamatan Kepulauan Pongok, Kabupaten Bangka Selatan, Provinsi Kepulauan Bangka Belitung pada bulan Februari 2018.

Penelitian melibatkan semua sekolah yang berada di kedua pulau tersebut. Sebagai penelitian pendahuluan, penelitian ini hanya menggunakan studi dokumentasi sebagai teknik pengambilan data. Studi dokumentasi yang dilakukan yaitu mengkaji dokumen-dokuken sekolah yang berkaitan dengan siswa, guru, dan sumber belajar. Hasil data yang terkumpul kemudian dianalisis secara deskriptif.

\section{HASIL DAN PEMBAHASAN}

Setelah penelitian dilakukan, tergambar bagaimana kondisi siswa, guru, dan sumber belajar pada sekolah di daerah kepulauan terpencil. Secera keseluruhan, terdapat 5 sekolah yang terlibat dalam penelitian. Kelima sekolah ini merupakan semua sekolah yang berada di pulau Pongok dan Celagen. Berikut ini profil sekolah sebagai gambaran karakteristik objek penelitian.

Tabel 1. Profil Sekolah di Pulau Pongok dan Celagen

\begin{tabular}{llllll}
\hline Nama & Pendirian & Status & Jadwal & Hari & Lokasi \\
\hline SMA 1 & 2008 & Negeri & Pagi & 5 & Pongok \\
SMP 1 & 1997 & Negeri & Pagi & 6 & Pongok \\
SD 1 & 1965 & Negeri & Pagi & 6 & Pongok \\
SD 2 & 1978 & Negeri & Pagi & 6 & Pongok \\
SD 3 & 1980 & Negeri & Pagi & 6 & Celagen \\
\hline
\end{tabular}

Tabel 1. menunjukkan ringkasan profil sekolah yang ada di pulau Pongok dan Celagen. Sekolah yang pertama didirikan di Pongok adalah Sekolah Dasar 1 (SD) pada tahun 1965. Ketiga SD dan Sekolah Menengan Pertama (SMP) sudah didirikan sejak lama sebelum tahun 2000. Sekolah Menengah Atas (SMA) satusatunya sekolah yang didirikan setelah tahun 2000, tepatnya pada tahun 2008. Semua sekolah merupakan sekolah negeri dengan jadwal masuk pada pagi hari. Hanya SMA yang sudah menerapkan kebijakan sekolah 5 hari, sedangkan yang lainnya masih masuk selama 6 hari dalam seminggu. Hampir semua sekolah berada di pulau Pongok dan hanya satu sekolah yang berada di pulau Celagen.

\section{Siswa pada Sekolah di Daerah Kepulauan Terpencil}

Berikut ini merupakan gambaran kondisi siswa pada sekolah di daerah kepulauan terpencil. Kondisi siswa tergambar mulai dari jenis kelamin, pekerjaan orang tua, dan tempat tinggal. Sayangnya, terdapat beberapa data yang kosong karena sekolah tidak memiliki dokumen tersebut, atau memilikinya namun tidak terdapat data yang detail dan terperinci. 
Tabel 2. Profil Peserta Didik berdasarkan Jenis Kelamin, Pekerjaan Orang Tua, dan Tempat Tinggal

\begin{tabular}{|c|c|c|c|c|c|c|}
\hline $\begin{array}{l}\text { Jenis } \\
\text { kelamin }\end{array}$ & Laki-laki & & Perempuan & & & Total \\
\hline SMA & $74(38.1 \%)$ & & $120(61.9 \%)$ & & & $194(100 \%)$ \\
\hline SMP & $129(53.3 \%)$ & & $113(46.7 \%)$ & & & $242(100 \%)$ \\
\hline SD 1 & $127(46.4 \%)$ & & $147(53.6 \%)$ & & & $274(100 \%)$ \\
\hline SD 2 & $82(57.7 \%)$ & & $60(42.3 \%)$ & & & $142(100 \%)$ \\
\hline SD 3 & $*$ & & $*$ & & & $162(100 \%)$ \\
\hline Total & $412(40.6 \%)$ & & $440(43.4 \%)$ & & & $1014(100 \%)$ \\
\hline $\begin{array}{l}\text { Pekerjaan } \\
\text { orang tua }\end{array}$ & PS & PNS & Petani & Pedagang & Nelayan & Total \\
\hline SMA & $10(5.2 \%)$ & $5(2.6 \%)$ & $30(15.5 \%)$ & $10(5.2 \%)$ & $100(51.5 \%)$ & $194(100 \%)$ \\
\hline SMP & $*$ & $*$ & $*$ & $*$ & $*$ & $242(100 \%)$ \\
\hline SD 1 & $24(8.8 \%)$ & $8(2.9 \%)$ & $45(16.4 \%)$ & $33(12.0 \%)$ & $164(59.9 \%)$ & $274(100 \%)$ \\
\hline SD 2 & $*$ & $*$ & $*$ & $*$ & $*$ & $142(100 \%)$ \\
\hline SD 3 & $0(0.0 \%)$ & $3(1.9 \%)$ & $0(0.0 \%)$ & $0(0.0 \%)$ & $159(98.1 \%)$ & $162(100 \%)$ \\
\hline Total & $24(2.4 \%)$ & $\begin{array}{l}16 \\
(1.6 \%)\end{array}$ & $75(7.4 \%)$ & $43(4.2 \%)$ & $423(41.7 \%)$ & $1014(100 \%)$ \\
\hline $\begin{array}{l}\text { Tempat } \\
\text { tinggal }\end{array}$ & Pongok & & Celagen & & & Total \\
\hline SMA & $*$ & & $*$ & & & $194(100 \%)$ \\
\hline SMP & $192(79.3 \%)$ & & $50(20.7 \%)$ & & & $242(100 \%)$ \\
\hline SD 1 & $274(100 \%)$ & & $0(0.0 \%)$ & & & $274(100 \%)$ \\
\hline SD 2 & $142(100 \%)$ & & $0(0.0 \%)$ & & & $142(100 \%)$ \\
\hline SD 3 & $0(0.0 \%)$ & & $162(100 \%)$ & & & $162(100 \%)$ \\
\hline Total & $608(60.0 \%)$ & & $212(20.9 \%)$ & & & $1014(100 \%)$ \\
\hline
\end{tabular}

Tabel 2. menunjukkan profil siswa berdasarkan usia, pekerjaan orang tua, dan tempat tinggal. Peserta didik perempuan pada SMA hampir dua kali lipat, yaitu sejumlah 120 (61.9\%), dibanding peserta didik laki-laki yang hanya berjumlah 74 (38.1\%). Peserta didik pada SMP, SD 1, dan SD 2 hampir berimbang antara laki-laki dan perempuan. Tidak ada data terkait jenis kelamin peserta didik pada SD 3, data yang ada hanya jumlah peserta didik secara keseluruhan. Mayoritas orang tua siswa bekerja sebagai nelayan. Tidak ada data terkait pekerjaan orang tua siswa pada SMP dan SD 2, data yang ada hanya jumlah peserta didik secara keseluruhan. Berkaitan dengan tempat tinggal, sebagian besar peserta didik tinggal di pulau Pongok. Tidak ada data terkait tempat tinggal peserta didik pada SMA.

\begin{tabular}{clll}
\multicolumn{6}{c}{ Tabel 3. Profil Lulusan SMA yang Melanjutkan ke Perguruan Tinggi } \\
\hline Angkatan & Lulusan & Lanjut ke PT & Persentase \\
\hline $2016 / 2017$ & 33 & 2 & $6.1 \%$ \\
$2015 / 2016$ & 44 & 2 & $4.5 \%$ \\
$2014 / 2015$ & 34 & 1 & $2.9 \%$ \\
$2013 / 2014$ & 47 & 3 & $6.4 \%$ \\
$2012 / 2013$ & 41 & 4 & $9.8 \%$ \\
\hline
\end{tabular}


Tabel 3. menunjukkan profil lulusan SMA yang melanjutkan ke perguruan tinggi dalam kurun waktu lima tahun terakhir. Pada setiap tahunnya, tidak lebih dari $10 \%$ lulusan yang melanjutkan pendidikan lebih lanjut ke perguruan tinggi. Jumlah paling banyak hanyalah 4 lulusan pada angkatan tahun 2012/2013, bahkan hanya ada 1 lulusan yang melanjutkan ke perguruan tinggi pada angkatan tahun 2014/2015.

\section{Guru pada Sekolah di Daerah Kepulauan Terpencil}

Berikut ini tergambar kondisi guru pada sekolah di daerah kepulauan terpencil. Kondisi guru tergambar mulai dari jenis kelamin, usia, latar belakang pendidikan, status, pengalaman mengajar, setifikasi, dan linieritas. Data tersebut tersaji dalam dua tabel yang berbeda supaya dapat tergambar dengan jelas. Semua sekolah memiliki data profil guru yang lengkap.

Tabel 4. Profil Guru berdasarkan Jenis Kelamin, Usia, dan Latar Belakang Pendidikan

\begin{tabular}{|c|c|c|c|c|c|c|c|c|}
\hline $\begin{array}{l}\text { Jenis } \\
\text { kelamin }\end{array}$ & Laki-laki & & \multicolumn{5}{|c|}{ Perempuan } & Total \\
\hline SMA & $8(53.3 \%)$ & & \multicolumn{5}{|c|}{$7(46.7 \%)$} & $15(100 \%)$ \\
\hline SMP & $10(71.4 \%)$ & & \multicolumn{5}{|c|}{$4(28.6 \%)$} & $14(100 \%)$ \\
\hline SD 1 & $11(52.4 \%)$ & & \multicolumn{5}{|c|}{$10(47.6 \%)$} & $21(100 \%)$ \\
\hline SD 2 & $4(44.4 \%)$ & & \multicolumn{5}{|c|}{$5(55.6 \%)$} & $9(100 \%)$ \\
\hline SD 3 & $5(50.0 \%)$ & & \multicolumn{5}{|c|}{$5(50.0 \%)$} & $10(100 \%)$ \\
\hline Total & $38(55.1 \%)$ & & \multicolumn{5}{|c|}{$31(44.9 \%)$} & $69(100 \%)$ \\
\hline Usia & $<25$ & $25-30$ & 31-35 & $36-40$ & $41-45$ & $46-50$ & $>\mathbf{5 0}$ & Total \\
\hline SMA & $\begin{array}{l}1 \\
(6.7 \%)\end{array}$ & $\begin{array}{l}3 \\
(20.0 \%)\end{array}$ & $\begin{array}{l}1 \\
(6.7 \%)\end{array}$ & $\begin{array}{l}2 \\
(6.7 \%)\end{array}$ & $\begin{array}{l}4 \\
(26.7 \%)\end{array}$ & $\begin{array}{l}3 \\
(20.0 \%)\end{array}$ & $\begin{array}{l}1 \\
(6.7 \%)\end{array}$ & $\begin{array}{l}15 \\
(100 \%)\end{array}$ \\
\hline SMP & $\begin{array}{l}2 \\
(14.3 \%)\end{array}$ & $\begin{array}{l}1 \\
(7.1 \%)\end{array}$ & $\begin{array}{l}3 \\
(21.4 \%)\end{array}$ & $\begin{array}{l}2 \\
(14.3 \%)\end{array}$ & $\begin{array}{l}3 \\
(21.4 \%)\end{array}$ & $\begin{array}{l}1 \\
(7.1 \%)\end{array}$ & $\begin{array}{l}2 \\
(14.3 \%)\end{array}$ & $\begin{array}{l}14 \\
(100 \%)\end{array}$ \\
\hline SD 1 & $\begin{array}{l}0 \\
(0.0 \%)\end{array}$ & $\begin{array}{l}5 \\
(23.8 \%)\end{array}$ & $\begin{array}{l}5 \\
(23.8 \%)\end{array}$ & $\begin{array}{l}6 \\
(28.6 \%)\end{array}$ & $\begin{array}{l}0 \\
(0.0 \%)\end{array}$ & $\begin{array}{l}0 \\
(0.0 \%)\end{array}$ & $\begin{array}{l}5 \\
(23.8 \%)\end{array}$ & $\begin{array}{l}21 \\
(100 \%)\end{array}$ \\
\hline SD 2 & $\begin{array}{l}0 \\
(0.0 \%)\end{array}$ & $\begin{array}{l}1 \\
(11.1 \%)\end{array}$ & $\begin{array}{l}2 \\
(22.2 \%)\end{array}$ & $\begin{array}{l}2 \\
(22.2 \%)\end{array}$ & $\begin{array}{l}2 \\
(22.2 \%)\end{array}$ & $\begin{array}{l}0 \\
(0.0 \%)\end{array}$ & $\begin{array}{l}2 \\
(22.2 \%)\end{array}$ & $\begin{array}{l}9 \\
(100 \%)\end{array}$ \\
\hline SD 3 & $\begin{array}{l}0 \\
(0.0 \%)\end{array}$ & $\begin{array}{l}2 \\
(20.0 \%)\end{array}$ & $\begin{array}{l}1 \\
(10.0 \%)\end{array}$ & $\begin{array}{l}0 \\
(0.0 \%)\end{array}$ & $\begin{array}{l}3 \\
(30.0 \%)\end{array}$ & $\begin{array}{l}2 \\
(20.0 \%)\end{array}$ & $\begin{array}{l}2 \\
(20.0 \%)\end{array}$ & $\begin{array}{l}10 \\
(100 \%)\end{array}$ \\
\hline Total & $\begin{array}{l}3 \\
(4.3 \%)\end{array}$ & $\begin{array}{l}12 \\
(17.4 \%)\end{array}$ & $\begin{array}{l}12 \\
(17.4 \%)\end{array}$ & $\begin{array}{l}12 \\
(17.4 \%)\end{array}$ & $\begin{array}{l}12 \\
(17.4 \%)\end{array}$ & $\begin{array}{l}6 \\
(8.7 \%)\end{array}$ & $\begin{array}{l}12 \\
(17.4 \%)\end{array}$ & $\begin{array}{l}69 \\
(100 \%)\end{array}$ \\
\hline Pend. & SMA & \multicolumn{2}{|c|}{ D3 } & \multicolumn{2}{|l|}{ S1 } & \multicolumn{2}{|c|}{ S2 } & Total \\
\hline SMA & $2(13.3 \%)$ & \multicolumn{2}{|c|}{$0(0.0 \%)$} & \multicolumn{2}{|c|}{$13(86.7 \%)$} & \multicolumn{2}{|c|}{$0(0.0 \%)$} & $15(100 \%)$ \\
\hline SMP & $1(7.1 \%)$ & \multicolumn{2}{|c|}{$2(14.3 \%)$} & \multicolumn{2}{|c|}{$11(78.6 \%)$} & \multicolumn{2}{|c|}{$0(0.0 \%)$} & $14(100 \%)$ \\
\hline SD 1 & $2(9.5 \%)$ & \multicolumn{2}{|c|}{$0(0.0 \%)$} & \multicolumn{2}{|c|}{$19(90.5 \%)$} & \multicolumn{2}{|c|}{$0(0.0 \%)$} & $21(100 \%)$ \\
\hline SD 2 & $2(22.2 \%)$ & \multicolumn{2}{|c|}{$0(0.0 \%)$} & \multicolumn{2}{|c|}{$7(77.8 \%)$} & \multicolumn{2}{|c|}{$0(0.0 \%)$} & $9(100 \%)$ \\
\hline SD 3 & $3(30.0 \%)$ & \multicolumn{2}{|c|}{$1(10.0 \%)$} & \multicolumn{2}{|c|}{$6(60.0 \%)$} & \multicolumn{2}{|c|}{$0(0.0 \%)$} & $10(100 \%)$ \\
\hline Total & $10(14.5 \%)$ & \multicolumn{2}{|c|}{$3(4.3 \%)$} & \multicolumn{2}{|c|}{$56(81.2 \%)$} & \multicolumn{2}{|c|}{$0(0.0 \%)$} & $69(100 \%)$ \\
\hline
\end{tabular}

Tabel 4. menunjukkan profil guru berdasarkan jenis kelamin, usia, dan latar belakang pendidikan. Secara keseluruhan dengan total guru sejumlah 69 guru, guru laki-laki $(55,1 \%)$ sedikit lebih banyak dibandingkan denga guru perempuan (44,9\%). Namun, khususnya pada SMP, guru laki-laki jauh lebih banyak dari pada guru perempuan dengan prosentase $71,4 \%$ banding $28,6 \%$. Rata-rata guru berusia 
antara 25 hingga 45 tahun. Terdapat 12 $(17,4 \%)$ guru yang memiliki usia di atas 50 tahun, sedangkan hanya terdapat $3(4,3 \%)$ guru yang berusia di bawah 25 tahun. Mayoritas guru berpendidikan Strata 1 (S1) yaitu sejumlah $56(81,2 \%)$. Masih terdapat
$3(4.3 \%)$ guru berpendidikan Diploma III dan $10(14,5 \%)$ guru berpendidikan SMA. Belum ada guru yang berpendidikan Strata 2 (S2).

Tabel 5. Profil Guru berdasarkan Status Kepegawaian, Pengalaman, Sertifikasi, dan Linieritas

\begin{tabular}{|c|c|c|c|c|c|c|}
\hline Status & GTT & & & PNS & & Total \\
\hline SMA & $8(53.3 \%)$ & & & $7(46.7 \%)$ & & $15(100 \%)$ \\
\hline SMP & $7(50.0 \%)$ & & & $7(50.0 \%)$ & & $14(100 \%)$ \\
\hline SD 1 & $8(38.1 \%)$ & & & $13(61.9 \%)$ & & $21(100 \%)$ \\
\hline SD 2 & $2(22.2 \%)$ & & & $7(77.8 \%)$ & & $9(100 \%)$ \\
\hline SD 3 & $5(50.0 \%)$ & & & $5(50.0 \%)$ & & $10(100 \%)$ \\
\hline Total & $30(43.5 \%)$ & & & $39(56.5 \%)$ & & $69(100 \%)$ \\
\hline Pengalaman & $<5$ & 5-10 & 11-15 & $16-20$ & $>20$ & Total \\
\hline SMA & $3(20.0 \%)$ & $7(46.7 \%)$ & $3(20.0 \%)$ & $1(6.7 \%)$ & $1(6.7 \%)$ & $15(100 \%)$ \\
\hline SMP & $4(28.6 \%)$ & $5(35.7 \%)$ & $1(7.1 \%)$ & $2(14.3 \%)$ & $2(14.3 \%)$ & $14(100 \%)$ \\
\hline SD 1 & $1(4.8 \%)$ & $9(42.9 \%)$ & $2(9.5 \%)$ & $4(19.0 \%)$ & $5(23.8 \%)$ & $21(100 \%)$ \\
\hline SD 2 & $0(0.0 \%)$ & $1(11.1 \%)$ & $4(44.4 \%)$ & $1(11.1 \%)$ & $3(33.3 \%)$ & $9(100 \%)$ \\
\hline SD 3 & $0(0.0 \%)$ & $2(20.0 \%)$ & $3(30.0 \%)$ & $3(30.0 \%)$ & $2(20.0 \%)$ & $10(100 \%)$ \\
\hline Total & $8(11.6 \%)$ & $24(34.8 \%)$ & $13(18.8 \%)$ & $11(15.9 \%)$ & $13(18.8 \%)$ & $69(100 \%)$ \\
\hline Sertifikasi & Belum & & & Sudah & & Total \\
\hline SMA & $10(66.7 \%)$ & & & $5(33.3 \%)$ & & $15(100 \%)$ \\
\hline SMP & $11(78.6 \%)$ & & & $3(21.4 \%)$ & & $14(100 \%)$ \\
\hline SD 1 & $12(57.1 \%)$ & & & $9(42.9 \%)$ & & $21(100 \%)$ \\
\hline SD 2 & $6(66.7 \%)$ & & & $3(33.3 \%)$ & & $9(100 \%)$ \\
\hline SD 3 & $4(40.0 \%)$ & & & $6(60.0 \%)$ & & $10(100 \%)$ \\
\hline Total & $43(62.3 \%)$ & & & $26(37.7 \%)$ & & $69(100 \%)$ \\
\hline Linier & Tidak & & & Ya & & Total \\
\hline SMA & $6(40.0 \%)$ & & & $9(60.0 \%)$ & & $15(100 \%)$ \\
\hline SMP & $4(28.6 \%)$ & & & $10(71.4 \%)$ & & $14(100 \%)$ \\
\hline SD 1 & $3(14.3 \%)$ & & & $18(85.7 \%)$ & & $21(100 \%)$ \\
\hline SD 2 & $2(22.2 \%)$ & & & 7 (77.8\%) & & $9(100 \%)$ \\
\hline SD 3 & $3(30.0 \%)$ & & & $7(70.0 \%)$ & & $10(100 \%)$ \\
\hline Total & $18(26.1 \%)$ & & & $51(73.9 \%)$ & & $69(100 \%)$ \\
\hline
\end{tabular}

Tabel 5. menunjukkan profil guru berdasarkan status kepegawaian, pengalaman, sertifikasi, dan linieritas. Terdapat 39 (56.5\%) guru yang sudah berstatus sebagai Pegawai Negeri Sipil (PNS), sedangkan yang lain masih berstatus sebagai Guru Tidak Tetap (GTT). Kebanyakan guru sudah memiliki pengalaman mengajar lebih dari 5 tahun. Hanya 8 guru (11.6\%) yang memiliki pengalaman mengajar di bawah 5 tahun.
Lebih dari $60 \%$ atau tepatnya sejumlah 43 guru belum tersertifikasi. Terdapat 18 (26.1\%) guru yang mengajar tidak sesuai dengan latar belakang pendidikannya.

\section{Sumber Belajar pada Sekolah di Daerah Kepulauan Terpencil}

Berikut ini tergambar kondisi sumber belajar pada sekolah di daerah kepulauan terpencil. Sumber belajar yang dimaksud di sini berfokus pada koleksi buku 
perpustakaan sekolah yang terbagi menjadi berbagai macam jenis, yaitu buku teks, buku pengayaan, buku referensi, buku panduan pendidik, dan buku lainnya.
Semua sekolah memiliki data tentang koleksi buku perpustakaan yang lengkap.

Tabel 6. Profil Koleksi Buku Perpustakaan Sekolah

\begin{tabular}{lclllll}
\hline Koleksi & \multicolumn{1}{c}{ B. Teks } & $\begin{array}{c}\text { B. } \\
\text { Pengayaan }\end{array}$ & \multicolumn{1}{c}{ B. Referensi } & $\begin{array}{c}\text { B. Pand. } \\
\text { Pend. }\end{array}$ & \multicolumn{1}{c}{ Lainnya } & \multicolumn{1}{c}{ Total } \\
\hline SMA & $2452(89.4 \%)$ & $148(5.4 \%)$ & $144(5.2 \%)$ & $0(0.0 \%)$ & $0(0.0 \%)$ & $2744(100 \%)$ \\
SMP & $3578(73.9 \%)$ & $118(2.4 \%)$ & $1125(23.2 \%)$ & $9(0.2 \%)$ & $12(0.2 \%)$ & $4842(100 \%)$ \\
SD 1 & $342(2.5 \%)$ & $7103(52.5 \%)$ & $5992(44.3 \%)$ & $97(0.7 \%)$ & $0(0.0 \%)$ & 13534 \\
SD 2 & $195(78.0 \%)$ & $30(12.0 \%)$ & $20(8.0 \%)$ & $0(0.0 \%)$ & $5(2.0 \%)$ & $250(100 \%)$ \\
SD 3 & $550(37.4 \%)$ & $209(14.2 \%)$ & $710(48.3 \%)$ & $0(0.0 \%)$ & $0(0.0 \%)$ & $1469(100 \%)$ \\
Total & $7117(31.2 \%)$ & $7608(33.3 \%)$ & $7991(35.0 \%)$ & $106(0.5 \%)$ & $17(0.1 \%)$ & $\begin{array}{l}22839 \\
(100 \%)\end{array}$ \\
\hline
\end{tabular}

Tabel 6. menunjukkan profil koleksi buku pada perpustakaan sekolah. Semua sekolah memiliki perpustakaan dengan beragam jenis buku koleksi. Kebanyakan koleksi merupakan buku teks pelajaran, buku pengayaan, dan buku refensi. Masih sangat minim koleksi buku panduan pendidik dan koleksi lainnya yang hanya sejumlah $106(0,5 \%)$ dan $17(0,1 \%)$ dari total keseluruhan koleksi.

Hasil penelitian ini mengkonfirmasi sekaligus menemukan hal-hal baru yang belum terungkap pada penelitian-penelitian sebelumnya. Pada beberapa sisi, hasil penelitian ini sangat dangkal tidak sedalam penelitian terdahulu yang sudah pernah dilakukan. Terutama terkait dengan kondisi siswa, penelitian ini hanya mengungkap data kuantitatif dan tidak menggali jauh sampai pada tingkat motivasi siswa seperti yang dilakukan oleh Handre, Sullivan, dan Crowson (2009). Namun, melalui penelitian ini terungkap bahwa sangat sedikit siswa lulusan SMA di daerah kepulauan yang melanjutkan studi ke perguruan tinggi. Hal ini mungkin disebabkan karena mayoritas orang tua mereka yang bekerja sebagai nelayan dan petani. Bukan karena biaya tidak ada karena pendapatan nelayan di daerah kepulauan cukup tinggi, hal tersebut disinyalir lebih dikarenakan tidak ada kemauan dari orang tua sekaligus rendahnya motivasi lulusan untuk melanjutkan ke perguruan tinggi. Lebih jauh dan mendalam, hal ini perlu diteliti lebih lanjut melalui penelitian lanjutan.

Angka partisipasi kasar (APK) pendidikan tinggi di Indonesia memang masih tergolong sangat rendah dibanding dengan Negara Asean lain seperti Malaysia dan Singapura yang masih-masing mencapai 38 dan $78 \%$ (Syawaluddin, 2018). Sedangkan, APK pendidikan tinggi Indonesia berdasarkan data pada Maret 2019 hanya 34\% yang artinya masih banyak anak Indonesia dengan usia 19-23 tahun belum berkesempatan mengenyam pendidikan tinggi. Meskipun, lima tahun kedepan, pemerintah melalui Kementerian Riset, Teknologi, dan Pendidikan Tinggi (Kemenristekdikti) menargetkan APK pendidikan tinggi Indonesia dapat mencapai 50\% (Republika Online, 2019). Sedikitnya lulusan SMA pada sekolah di daerah $3 \mathrm{~T}$ yang melanjutkan belajar pada perguruan tinggi turut menyumbang rendahnya APK pendidikan tinggi Indonesia.

Tidak seperti hasil penelitian yang dilakukan oleh Yosada (2017) dan Ginting (2016), jumlah guru di Pongok dan Celagen 
sudah tercukupi. Namun, hasil penelitian ini mengungkap lebih jauh bahwa betul kualitas guru rendah, yang disinyalir hal tersebut dikarenakan masih banyak guru yang memiliki latar belakang pendidikan strata 1 bukan dari jurusan kependidikan. Sedikitnya lulusan sarjana pendidikan didaerah Pongok dan Celagen membuat banyaknya lulusan sarjana non-pendidikan turut mengajar di sekolah untuk memenuhi kekosongan guru. Meskipun, sebetulnya, hal tersebut membawa masalah baru, mengingat linieritas keilmuan sangat penting demi terjaganya kualitas pembelajaran dan pendidikan. Selain itu, banyak guru yang mendapat gelar sarjana pendidikan setelah mereka sudah mengajar bertahun-tahun dengan megikuti program perkuliahan jarak jauh.

Dalam konteks pelaksanaan pendidikan di Pongok dan Celagen, sarana dan prasarana yang ada sudah mencukupi termasuk koleksi buku perpustakaan. Namun, terdapat satu jenis koleksi yang luput dari perhatian karena sebagain besar perpustakaan sekolah tidak memilikinya, yaitu koleksi buku panduan pendidik. Padahal, koleksi tersebut dapat dikatakan sangat penting sebagai referensi dan bahan belajar para guru untuk dapat terus meningkatkan kompetensinya dengan mandiri secara berkelanjutan. Apalagi, para guru yang berada di pulau terpencil sangat susah mengakses toko buku dan mengikuti berbagai pelatihan terkait dengan peningkatan profesionalisme guru.

Secara keseluruhan, hasil penilitian ini menunjukkan perlu adanya tinjauan kembali terhadap pelaksanaan pendidikan di daerah terpencil atau daerah sejenis yang termasuk dalam wilayah 3T. Pemerintah pusat bersama dengan pemerintah daerah nampaknya terus berupaya meningkatkan kualitas dan kuantitas pelaksanaan pendidikan di daerah $3 \mathrm{~T}$ secara bertahap namun berkelanjutan, sehingga marjinalisasi pendidikan di daerah 3T sudah mulai berkurang secara perlahan. Kedepan, kualitas dan kuantitas pelaksanaan pendidikan di daerah 3T akan sama baiknya dengan sekolah di perkotaan dan semuanya akan sesuai dengan standar nasional pendidikan.

Pemerintah melalui Kementerian Perencanaan Pembangunan Nasional atau Bappenas telah menggalakkan berbagai program untuk mengatasi kesenjangan antar wilayah dan ketertinggal suatu daerah yang sampai saat ini mejadi isu yang harus diatasi sejalan dengan tujuan pembangunan nasional (Bappenas, 2016). Kabar baiknya adalah, bahwa jumlah daerah tertinggal di Indonesia semakin tahun semakin berkurang. Sudah semakin banyak daerah yang terentaskan dari ketertingalannya. Pelayanan dasar di bidang pendidikan dan kesehatan menjadi salah satu prioritas dalam pembangunan kedepan.

\section{SIMPULAN}

Potret pendidikan di pulau Pongok dan Celagen memiliki beberapa kemiripan sekaligus perbedaan dengan kondisi pendidikan di daerah kepulauan atau pada wilayah 3T lainnya. Sedikitnya lulusan SMA yang melanjutkan ke perguruan tinggi, masih terdapat cukup banyak guru yang berlatar belakang pendidikan strata 1 non-kependidikan, dan hampir tidak adanya koleksi buku panduan pendidik pada sekolah di Pongok dan Celagen harus menjadi perhatian yang serius bagi para pemangku kepentingan atau kebijakan terkait dengan dunia pendidikan di wilayah terkait. Penelitian yang hanya bersumber dari studi dokumentasi ini memiliki banyak keterbatasan, sehingga penelitian selanjutnya diharapkan dapat dilakukan menggunakan beragam metode penelitian dan teknik pengumpulan data untuk memperdalam hasil penelitian khususnya yang berkaitan dengan motivasi siswa, 
kualitas guru, dan kelengkapan berbagai sumber belajar.

\section{DAFTAR RUJUKAN}

A'ing, A. (2015). Studi tentang pembangunan bidang pendidikan di daerah perbatasan Kecamatan Kayan Hulu Kabupaten Malinau. eJournal Pemerintahan Integratif, 3.

Adlim, M., Gusti, H., \& Zulfadli, Z. (2016). Permasalahan dan solusi pendidikan di daerah kepulauan: Studi kasus di SMA negeri 1 Pulau Aceh, Kabupaten Aceh Besar. Jurnal Pencerahan, 10(2).

Auldina, L. (2018). Marginalisasi pendidikan di daerah perbatasan (studi kasus di Desa Mapur Kecamatan Bintan Pesisir Kabupaten Bintan Provinsi Kepulauan Riau). Retrieved from http://repository.umrah.ac.id/826/

Badan Pusat Statistik Kabupaten Bangka Selatan. (2017). Kecamatan Kepulauan Pongok dalam Angka. Bangka Selatan: Badan Pusat Statistik.

Bappenas. (2016). Laporan akhir koordinasi strategis percepatan pelaksanaan program pembangunan daerah tertinggal untuk mendukung PP No. 78 Tahun 2014 dan Perpres No. 131 Tahun 2015. Jakarta: Bappenas.

Baswedan, A. R. (2014). Gawat darurat pendidikan di Indonesia. In the Emergency of Indonesian Education. A paper delivered at the meeting between Ministry and Head of Education Offices Indonesia-wide in Jakarta, on December (Vol. 1).

Campbell, A. M., \& Yates, G. C. (2011). Want to be a country teacher? No, I am too metrocentric. Journal of Research in Rural Education, 26.

Ginting, A. M. (2016). Kendala pembangunan provinsi daerah kepulauan: Studi kasus Provinsi Kepulauan Riau. Jurnal Politica
Dinamika Masalah Politik Dalam Negeri dan Hubungan Internasional, 4(1).

Handre, P. S., Sullivan, D., \& Crowson, H. (2009). Student characteristics and motivation in rural high school. Journal of Researchers Rural Education, 24(166), 1-19.

Imran, M. (2014). Pendidikan masyarakat terpencil di Dusun Tompu Desa Loru Kecamatan Sigi Biromaru. GeoTadulako, 1(2).

Londa, V. (2016). Implemenasi kebijakan pendidikan dasar daerah kepulauan (Studi di Kabupaten Kepulauan Talaud Provinsi Sulawesi Utara). Sosiohumaniora, 18(3), 263271.

Republika Online. (2019, March 11). Kemenristekdikti Targetkan Angka Partisipasi Kasar 50 Persen. Retrieved 26 September 2019, from Republika Online website: https://republika.co.id/share/po7dhq42 $\underline{8}$

Suardi, F., Sulfasyah, S., \& Nur, H. (2016). Diskriminasi pendidikan masyarakat terpencil. Jurnal Equilibrium Pendidikan Sosiologi, 4(2).

Syawaluddin, F. A. (2018, March 24). Rendahnya Angka Partisipasi Kasar Pendidikan Tinggi. Retrieved 26 September 2019, from GEOTIMES website:

https://geotimes.co.id/opini/rendahnyaangka-partisipasi-kasar-pendidikantinggi/

Yosada, K. R. (2017). Pendidikan di Beranda Terdepan Negara Perbatasan Entikong. Prosiding Seminar Nasional: Penguatan Hubungan antara Pengembangan Keterampilan, Pendidikan, dan Ketenagakerjaan Generasi Muda (pp. 192-201). 